The Middle East and Globalization 
This page intentionally left blank 


\title{
The Middle East and GLOBALization
}

\author{
ENCOUNTERS AND HoRIZONS
}

Edited by Stephan Stetter

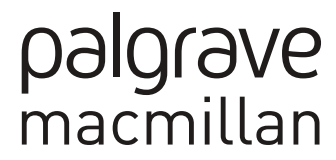




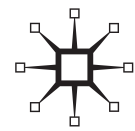

THE MIDDLE EAST AND GLOBALIZATION

Copyright (C) Stephan Stetter, 2012

Softcover reprint of the hardcover 1st edition 2012 978-1-137-03175-4

All rights reserved.

First published in 2012 by PALGRAVE MACMILLAN® in the United States-a division of St. Martin's Press LLC, 175 Fifth Avenue, New York, NY 10010.

Where this book is distributed in the UK, Europe and the rest of the world, this is by Palgrave Macmillan, a division of Macmillan Publishers Limited, registered in England, company number 785998, of Houndmills, Basingstoke, Hampshire RG21 6XS.

Palgrave Macmillan is the global academic imprint of the above companies and has companies and representatives throughout the world.

Palgrave ${ }^{\circledR}$ and Macmillan ${ }^{\circledR}$ are registered trademarks in the United States, the United Kingdom, Europe and other countries.

ISBN 978-1-349-44085-6 ISBN 978-1-137-03176-1 (eBook) DOI $10.1057 / 9781137031761$

Library of Congress Cataloging-in-Publication Data is available from the Library of Congress.

A catalogue record of the book is available from the British Library.

Design by Scribe Inc.

First edition: December 2012

1098766543221 
This book is dedicated by the authors summoned in this volume to the memory of Fred Halliday, 1946-2010 
This page intentionally left blank 


\section{Contents}

Preface

1 The Middle East and Globalization:

Encounters and Horizons

Stephan Stetter

\section{Part 1: Fractured Encounters}

2 Globalization, the Highest Stage of Imperialism:

Core-Periphery Dynamics in the Middle East

Raymond Hinnebusch

3 Globalization and Networked Civility

in the Arab Region

Emma Murphy

4 Globalization and In/Security:

Middle Eastern Encounters with

International Society and the Case of Turkey

Pinar Bilgin

5 The Globalization of Democracy and the Location of the Middle East in the Contemporary Global Order

Andrea Teti

6 Globalization in a Middle Eastern Regional

Perspective: A Postcolonial Reading of the

Arab Human Development Reports

Mervat F. Hatem

7 Settler Colonialism and Its Discontents:

A View Forward from the Long 1960s 


\section{Part 2: Horizons of the Global Condition}

8 The Middle East, Interstate Norms, and Intervention: The Great Anomaly Fred Halliday

9 Islamic Reform and the Global Public Sphere: Muhammad Abduh and Islamic Modernity Dietrich Jung

10 The "New Middle East" and the Encounter with the Global Condition: Exploring the Global/ Regional Interplay from the Perspective of the New English School Morten Valbjørn

11 Global Conflict Governance in the Middle East: World Society, Conflict Management in Lebanon, and the International Crisis Group Mitra Moussa Nabo and Stephan Stetter

12 Globalization, Labor Migration, and Cities in Israel

Haim Yacobi

13 The Arab State, Identity, and Social Progress: Egypt, Globalization, and the Challenges of Integration Robert Bowker

References

Contributors

Index 


\section{PREFACE}

The chapters in this book were first presented at an authors' conference I had organized at the Georg-von-Vollmar-Akademie in Kochel am See, Upper Bavaria, in October 2009. The original idea of this conference was to bring together scholars from the Middle East, Europe, and the United States who work on the Middle East from theoretical perspectives that, in one way or another, are informed by theories of globalization and world society. This idea had ripened after I published my monograph with Palgrave Macmillan on World Society and the Middle East: Reconstructions in Regional Politics back in 2008. While I had drawn from a specific theory of globalization in that booknamely, the theory of world society in modern systems theory - it was obvious that there are other equally fascinating globalization and world society theories waiting to be studied in relation to the Middle East but that I had decided not to focus on in that book. I thus approached colleagues in my field who shared my theoretical and empirical passion for globalization and Middle East studies and invited them to the workshop. Their papers were presented there in draft format and then subsequently revised. Apart from comments received at the workshop, each author was able, in her or his revision, to draw from a conceptual umbrella that we had jointly developed during the conference. The notion of encounters and horizons originates from these discussions. Moreover, I discussed these chapters with students in the MA social sciences program at the Universität der Bundeswehr München and forwarded their comments to the authors. The critical engagement of students in the classroom interested in and fascinated by politics in the region was a particularly pleasant and joyful part of preparing this book.

A project like this one would not have been possible without the support of many individuals and organizations. I am, first of all, grateful to my university, the Universität der Bundeswehr München, not only for offering excellent working conditions for my research and teaching on the Middle East, but also for providing me with financial resources that allowed me to approach my colleagues and invite all them to the aforementioned conference. When organizing the conference, my student assistants Christian Gschwilm and Fabian Poetke and my secretary Mrs. Angelika Schoppel were a great support, too. Many thanks as well to the staff at the Vollmar-Akademie, a beautiful venue 
for focused and inspiring academic exchanges, and not only due to its Alpine setting. I would also like to express my gratitude to Palgrave Macmillan. When I approached Palgrave I immediately found great support for this project, and Farideh Koohi-Kamali, Sara Doskow, and Sarah Nathan have been efficient and supportive throughout the publication process. Many thanks to Daniel J. King, who was a very good copyeditor for this book. I am also grateful to the anonymous referee who supported publication of this project and made important suggestions for fine-tuning parts of the book. My greatest thanks go to my student assistant Sebastian Schmitz who has supported me immensely in preparing a final manuscript that meets all formal and technical requirements. My student assistants Caroline Wegener and Sebastian Krauß have also assisted in that effort. Special thanks to Hagit Keysar for granting permission to reproduce one of her photographs of the East Jerusalem neighborhood of Silwan as the image on the book cover. The picture stems from a research project by Hagit in which Palestinian kids from Jerusalem took aerial pictures of their city by means of a simple camera attached to a balloon.

Fred Halliday, from whose impressive theoretical and empirical work on the Middle East all the authors summoned in his book have drawn so much, had been invited to our meeting. Fred had sent his paper prior to the meeting but due to his state of health had to cancel his participation a week before the workshop. He did not fully recover afterward. Only six months later, in April 2011, Fred Halliday passed away. This was and is to remain a great loss; academia in general, and Middle East studies in particular, has lost not only an intellectual icon but also a truly cosmopolitan and likeable colleague as well as, for many of the authors contributing to this book, a good friend.

Fred was not able to revise his chapter, but his Executor of Estate granted permission to print his chapter in its original version. There was no question for me nor for the other authors and the publisher that his contributionprobably one of the last pieces he has written-should be printed in this book, which we herewith dedicate to the memory of Fred Halliday. 